\title{
Evaluation of estuarine biotic indices to assess macro-benthic structure and functioning following nutrient remediation actions: A case study on the Eden estuary Scotland.
}

\author{
Stephen C.L. Watson ${ }^{a, b}$, David M. Paterson ${ }^{a}$, Stephen Widdicombe ${ }^{b}$, Nicola J. \\ Beaumont ${ }^{b}$.
}

aSchool of Biology, Sediment Ecology Research Group, Scottish Oceans Institute, University of St Andrews, East Sands, St. Andrews, Fife, KY16 8LB, UK

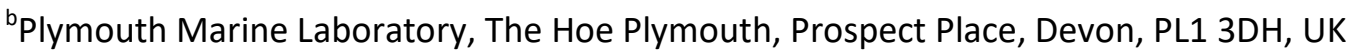

*Corresponding author swatson@bournemouth.ac.uk

Keywords: Ecological indicators, Macro-invertebrates, Estuarine recovery, Ecological quality, MAMBI, Biological Traits Analysis (BTA).

\begin{abstract}
Despite a wealth of methods currently proposed by the European Water Framework Directive (WFD) to assess macro-benthic integrity, determining good ecological status (GES) and assessing ecosystem recovery following anthropogenic degradation is still one of the biggest challenges in marine ecology research. In this study, our aim was to test a number of commonly used structural (e.g. ShannonWiener, Average Taxonomic Diversity ( $\triangle$ ), M-AMBI) and functional indictors (e.g. BTA, BPc) currently used in benthic research and monitoring programmes on the Eden estuary (Scotland). Historically the estuary has a legacy of high nutrient conditions and was designated as a Nitrate Vulnerable Zone (NVZ) in 2003, whence major management measures were implemented in order to ameliorate the risk of eutrophication symptoms. We therefore collected data on intertidal macro-benthic communities over a sixteen year interval, covering a pre-management (1999) and post-management (2015) period to assess the effectiveness of the intended restoration efforts. In the postmanagement period, the results suggested an improvement in the structure and functioning of the estuary as a whole, but macro-benthic assemblages responded to restoration variably along the estuarine gradient. The greatest improvements were noticed in the upper and central sites of the estuary with functional traits analysis suggesting an increased ability of these sites to provide ecosystem services associated with the benthic environment such as carbon and organic matter cycling. Generally, almost all of the structural and functional indicators detected the prevailing environmental conditions (with the exception of (Pielou's index and Average Taxonomic Diversity $(\Delta)$ ), highlighting the appropriateness of such methods to be used in monitoring the recovery of transitional systems. This research also provides a robust baseline to monitor further management actions in the Eden estuary and provides evidence that notable reductions in nitrate concentrations resulting from NVZ designations may result in significant improvements to benthic structure and functioning.
\end{abstract}




\section{Introduction}

Following different legislative mandates to assess the status of marine and coastal ecosystems (e.g. Marine Strategy Framework Directive (MSFD) 2008/56/EU and Water Framework Directive (WFD), $2000 / 60 / E C$ ), there is an increasing need to evaluate ecological quality following environmental restoration resulting from reducing human-induced pressures (Elliott et al., 2007; Borja et al., 2010). In estuarine systems a plethora of methodologies, indices, metrics and evaluation tools are presently available to assess ecological integrity (Borja \& Dauer, 2008) and have been widely used for quality status assessments mainly through the analysis of macro-benthic communities (e,g, Veríssimo et al., 2012a; Tweedley et al., 2015). In particular, over the last few decades there has been considerable research into understanding how changes in biodiversity can lead to changes in the structure and functioning of transitional ecosystems (e.g. Balvanera, et al., 2006; Cardinale et al., 2006; Strong et al., 2015). Conventional approaches to assess ecosystem recovery have often been based on structural or taxonomic elements of taxa, such as changes in abundance or taxonomic composition (Warwick \& Clarke, 1995; Clarke \& Warwick, 2001), however functional aspects (or traits) of species with assemblages have become increasing examined as potential indicators of environmental change (Crowe \& Russell 2009; Petchey et al., 2009). Two such groups of metrics that have proven useful when trying to categorise and understand ecosystem function when conducted in benthic communities, are biological traits analysis (BTA, Bremner et al., 2003; 2006a) and bioturbation potential (BPC) related indices (e.g. Solan et al., 2004; Queirós et al., 2013). Therefore, testing the performance of these indices in novel systems has gained relevancy, in order to incorporate aspects of a system functioning into conservation and management efforts (Bremner et al., 2008).

Among the most relevant issues for environmental regulators and policymakers is the problem of eutrophication, with nitrogen and phosphorus inputs accounting for the largest volume of anthropogenic wastes added to estuaries and coastal systems (Kennish, 1996; Howarth et al., 2011). Yet, while the eutrophication process leading to ecosystem degradation is now well studied and understood (e.g., Elliott \& De Jonge, 2002; Howarth \& Marino, 2006; Orive et al., 2013) our knowledge on coastal ecosystem recovery following significant nutrient reductions is more limited (Steckbauer et al., 2011; Duarte et al., 2015) and often suffers from the scarcity of long-term, largescale ecosystem studies (Rieman et al., 2016). This study therefore constitutes one of the first attempts at investigating long term effects of nutrient reduction management measures in the Eden estuary, a small macrotidal system located on the eastern coast of Scotland, UK. Due to the high regional importance of agriculture within the catchment, anthropogenic pressure in the form of increased nutrients from arable land and livestock production have traditionally been one of the most significant pressures influencing the estuary with high levels of nitrogen compounds entering the estuary via the river Eden (Clelland, 1997). Following a progressive deterioration in ecological quality in the late 90's, the catchment was designated as a Nitrate Vulnerable Zone (NVZ) in 2003 (SEERAD, 2003), whence major management measures were implemented in order to lessen the eutrophication symptoms recorded throughout the estuary. As a result, water quality data analysed by Macgregor \& Warren (2016) demonstrate that nitrate $(\mathrm{N})$ in the catchment's main rivers dropped between 2004 and 2011 by a mean of 15.5\%. This is thanks to increased legislation resulting from the Nitrates Directive and Sensitive Area (UWWTD) designations, including an upgrade of the Guardbridge sewage treatment works in 2008 and the closure of the Guardbridge paper mill and adjacent pig farm with their associated effluent. However, to date there is limited information on how these changes have influenced the resident biota of the estuary. 
The aim of this study therefore, was to assess the effectiveness of this recovery action on the resident macro-benthic biota. In particular, we searched for differences in ecological condition over a sixteen year interval (1999-2015), covering two periods (pre- and post-management). Calculations of three different categories of ecological indicators were performed based on (1) structure (Shannon-Wiener, Pielou, Margalef, Simpson and Taxonomic Diversity measures); (2) ecological groups (AMBI, IQI); and (3) functional traits (BTA and BPc). Structural and ecological group indicators were chosen due to their widespread use in the characterisation of benthic communities (Borja et al., 2009) and also due to their frequent inclusion in several of the multimetric indices that are being tested under the scope of the WDF (e.g. IQI). Functional diversity indicators were chosen primarily for their ability to describe a number of benthic supporting and regulatory ecosystem services (e.g. carbon and nutrient cycling Bremner et al., 2006a; Queirós et al., 2013) and to assess their potential to be used in benthic monitoring programmes.

\section{Materials and Methods}

\subsection{Eden estuary characterisation}

The Eden estuary is a small ( $11 \mathrm{~km}$-long) shallow bar built or 'pocket' estuary, located between the village of Guardbridge and the town of St. Andrews on the south-east coast of Scotland $\left(56^{\circ} 22^{\prime} \mathrm{N}\right.$, $2^{0} 50^{\prime}$ W). Collectively the Eden estuary along with the Firth of Tay Estuary is designated as a Special Area of Conservation (SAC) under the European Union's Habitats Directive (92/43/EEC) and a Special Protection Area (SPA) under the European Commission Directive on the Conservation of Wild Birds (79/409/EEC). The Eden estuary itself is also classified as a Local Nature Reserve (LNR), Site of Special Scientific Interest (SSSI) and RAMSAR site (Wetlands of International Importance). Historically the intertidal mud and sand flats of the estuary have been sampled intensively by researchers from the University of St. Andrews, with many studies undertaken from of the Gatty Marine Laboratory (Bennett \& McLeod, 1998) providing a robust baseline from which to draw comparisons.

Physically, the main source of fresh water into the catchment comes from the river Eden (draining $260 \mathrm{~km}^{2}$ out of $320 \mathrm{~km}^{2}$ ) which roughly dissects the catchment from west to east. Residence time of fresh water in the estuary is estimated to be approximately 6 days at average river flow. Wave heights have between recorded up to 0.4-1.0 metres (Duck et al., 2005) with equinoctial tidal ranges of $3.5 \mathrm{~m}, 5 \mathrm{~m}$ and $6 \mathrm{~m}$ respectively (Duck \& Wewetzer, 2001). The main channel of the estuary is flanked by relatively wide intertidal areas $\left(8 \mathrm{~km}^{2}\right)$ that plays host to large populations of overwintering waterfowl and wading bird species. Surrounding the Eden, the hinterland is highly developed, comprising; Leuchers army station; St. Andrews Links, the largest public golf complex in Europe; Eden.Mill, Scotland's first brewery-distillery (formally Guardbridge Paper Mill); and large swathes of highly productive agricultural land, that make up $76 \%$ of the land use within the catchment (Macgregor \& Warren, 2006).

\subsection{Sampling and analytical procedures}

Two time periods were considered for this study: (a) a "Pre-management period" in 1999, before the implementation of the NVZ when the estuary was considered to be in a high nutrient state and (b) a "Post-management period", in 2015 following extensive management restoration actions. Data for the 1999 period was collected as part of a large European project to assess the biological and physical dynamics of intertidal sediment systems called the BIOPTIS programme (MAS3-CT97-0158). During the BIOPTIS campaign, intertidal soft-bottom macro-benthic communities were sampled 
according to three sampling grids that were established across three transitional areas of the estuary (Figure 1) allowing for most of the natural variability between different physical and biological conditions within the estuary to be covered. Situated on the muddy-sandy Kincaple flats of the inner Eden estuary, Grid A $(900 \mathrm{~m} \times 500 \mathrm{~m})$ consisted of 52 sampling gridpoints, spaced $100 \mathrm{~m}$ apart, running from the top shore down to the channel of the river Eden. The site is dominated by a large Enteromorpha bed that is located in the mid to low shore region of the site. Situated further upstream, on a muddy tidal flat at the mouth of the River Eden, Grid B $(800 \mathrm{~m} \times 500 \mathrm{~m})$ consisted of 46 sampling gridpoints spaced $100 \mathrm{~m}$ apart, with the channel of the river Eden running through a portion of the site, running east to west. Finally, Grid C (200m x 300x) consisted of 12 sampling gridpoints spaced $100 \mathrm{~m}$ apart, situated on the exposed sandy region known as West Sands at the mouth of the estuary

Using each grid at each test site as a template, in 2015, ground based measures of macro-fauna were collected along a single vertical transect of the original BIOPTIS sampling grids (Figure 1). At each gridpoint station, three replicates were randomly collected using a $19 \mathrm{~cm}$ diameter $\left(0.028 \mathrm{~m}^{2}\right)$ stovepipe core to match with the BIOPTIS survey. All samples were taken within $5 \mathrm{~m}$ either side of the sampling location from undisturbed sediment, to a constant depth $(15 \mathrm{~cm})$ with the location of each sample point determined during the 2015 campaign using a Garmin eTrex hand held GPS device. The depth of the cores was based on, a small-scale depth study undertaken concurrently with the original BIOPTIS macro-faunal sampling, with the results suggesting that the vast majority of organisms (>95\%) were located in the upper $15 \mathrm{~cm}$ across all sampling sites. Exceptions to this rule included deep burrowing organisms such as Arenicola marina, Mya arenaria and in some cases Corophium volutator all of which were recorded at depths of over $20 \mathrm{~cm}$.

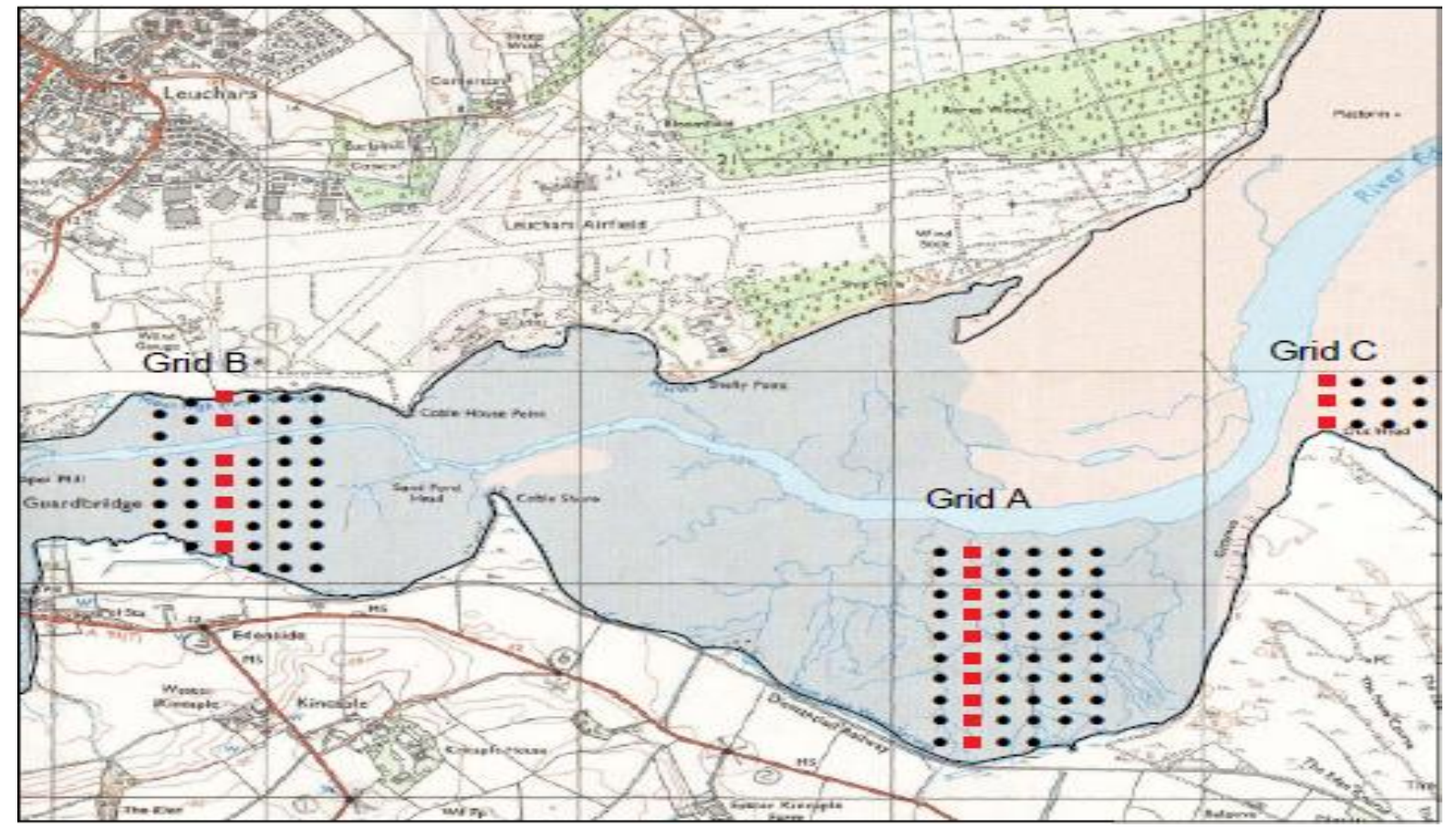

Figure 1 Location of the inter-tidal sampling grids and the different sites along the Eden estuary showing Grid A (Central), Grid B (Upper), Grid C (Lower). Black circles represent the 1999 sampling stations, while the red squares represent the stations sampled during the 2015 campaign. 
Samples were then returned to the laboratory and gently sieved through a $1 \mathrm{~mm}$-grade mesh sieve to match the BIOPTIS survey protocols. The biological material was initially preserved in $4 \%$ buffered formaldehyde and after sorting was kept in $70 \%$ ethanol, until posterior counting and identification. Macro-fauna were identified to species level where possible, with all fauna in tubes extracted for identification. In addition to classifying the fauna into species, individuals were assigned to major taxonomic groups for statistical assessment. These groups were Polychaetes, Crustaceans, Molluscs, and Oligochaetes; while individuals from a number of other small groups including Echinoderms, Holothurians, Nemerteans, Cnidarians, Bryozoans and Sipunculids were classified as 'Others'. Although no living Arenicola marina were collected, their presence at site $\mathrm{C}$ was apparent by numerous coiled castings and therefore this species was enumerated by an alternative method. Cast counts from each replicate were averaged, normalised to core size and used to estimate the average number of active Arenicola marina using the methodology outlined by Ford \& Honeywill (2002). Prior to calculations both abundance and biomass data were standardised to $\mathrm{m}^{2}$ (ind $\mathrm{m}^{-2}$ and $\mathrm{g}$ AFDW $\mathrm{m}^{-2}$, respectively). Where necessary wet weight biomass was converted to AFDM using published conversion factors in Brey's (2001) Virtual Handbook on Population Dynamics, version 4 (Brey.,2012, (www.awibremerhaven.de/Benthic/Ecosystem/ FoodWeb/Handbook/main.htm) and calculated using case study specific relationships (e.g. Biles et al., 2002).

\subsection{Ecological indicators}

\subsubsection{Structural indicators: description and computation.}

Six univariate biotic indicators were calculated from the benthic density data using the DIVERSE routine in the PRIMER (Plymouth Routines in Multivariate Analysis of Variance) package v7 (Clarke et al., 2014). The indicators were species richness (S), Shannon Wiener ( $H$; Shannon \& Wiener, 1963), Simpson's Dominance (Ds; Simpson, 1949), Margalef's Species Richness (D; Margalef, 1958), and Pielou's Evenness (J; Pielou, 1969). Using the same PRIMER package a number of phylogenetic indices first proposed by Warwick \& Clarke (1995) were also estimated using a hierarchical Linnean classification system with the Average Taxonomic Diversity $(\Delta)$, Average Taxonomic Distinctness (AvTD) and Total Taxonomic Distinctness (TTD) indices used as a proxy for the relatedness between individuals within an assemblage. Specifically $\Delta$ was used to represent the average taxonomic distance between every pair of individuals in the sample (Clarke \& Warwick, 1999) while AvTD and TTD were used to represent the taxonomic breadth between pairs of species with a sample (Clarke \& Warwick., 2001). The latter two indices were calculated based on presence/absence data, leaving measures closer to a pure reflection of taxonomic hierarchy. To determine benthic habitat quality or Ecological Status (ES) sensu the WFD, outputs of two multi-metric indices: Multivariate AMBI (M$A M B I)$ and the Infaunal Quality Index (IQI) were also calculated. As a prerequisite to both indices AZTI'S Marine Biotic Index (AMBI) was first calculated using the AMBI 5.0 software tool available from AZTI'S webpage (http://www.azti.es) using the recommendations outlined by the authors (Borja et al., 2012). Secondly the UK and Irish Infaunal Quality Index (IQI) version 4 was used to calculate a Benthic Ecological Quality Ratio (EQR) using a proprietary tool in Microsoft Excel developed by the UK Environment Agency (Phillips et al., 2012). The relative performance of each indicator to detect ecological changes between each time period was assessed based on the classification proposed by the indicator developers and also by multivariate analysis. For instance, high values for Margalef, Shannon-Wiener, Pielou, taxonomically based indicators, M-AMBI and IQI are indicative of a high ecological status, while high values for Simpson's index would suggest low 
ecological status. As such, according to the classification proposed we would expect higher values for Margalef, Shannon-Wiener, Pielou, the taxonomically based indicators, M-AMBI and IQI measures in the post-management period and the Simpson index should present the opposite behaviour with a decrease in value.

\subsubsection{Functional indicators: description and computation}

To assess the relative ecological functioning of each system, two metrics; biological traits analysis (BTA) and bioturbation potential (BPc) were calculated from the previously identified benthic taxa data sets. Following Bremner et al., (2003, 2006a) seven biological traits (Maximum Size, Adult Longevity, Growth Form, Feeding Method, Environmental Position, Mobility in Sediment and Reproductive Method) were selected covering different aspects of life history, morphology and behaviour of each taxa (Table 1). In addition to these traits, two further traits were added to the list namely; Bioturbation functional type-constructed from the standardised scores for mobility and sediment reworking mode listed in Queirós et al. (2013) and species ecological group- based on the previously calculated $A M B I$ index. The $A M B I$ index has been used in in other BTA studies (e.g. Paganelli et al., 2012) as an additional ecological characteristic and classifies species according to their tolerance to disturbance. The trait "salinity preference" was also added due its known importance as environmental filtering trait in transitional ecosystems such as estuaries (Piscart et al., 2006; Linden et al., 2012). Traits were then subdivided into thirty-six categories that display the organisms' behaviour/strategy into more detail (e.g. the four considered categories of the trait 'feeding method' for benthic invertebrates were deposit, filter/suspension opportunist/scavenger and predator).

Having identified important traits, actual computation of BTA required the construction of three different numerical matrices: (1) taxa density in each station (matrix 'taxa by stations'); (2) biological traits of the taxa (matrix 'taxa by traits'); and (3) a combination of the previous two, biological traits in each station (matrix 'traits by stations') (e.g. Bremner et al., 2003). Data of taxa density were first sorted by year and site. As biomass is often cited as the best measure of an organisms presence in a community (e.g. Bremner et al., 2006b), the biological numeration system used here was biomass (g AFDW per $\mathrm{m}^{-2}$ ). Information for assigning taxa to functional traits and used to construct the 'taxa by traits' data matrix, was obtained from different published sources (see Appendix 1 ) including online databases such as BIOTIC developed by the Marine Life Information Network - UK (http://www.marlin.ac.uk/biotic/). When reliable information was missing, expert judgment and/or data from the nearest phylogenetic neighbour were considered. Using this information each taxon (i.e. species) was given a score from zero to three for the extent to which it exhibits each trait category, using a 'fuzzing coding' approach (Chevenet et al., 1994). An affinity score of ' 0 ' indicates no affinity of a taxon to a trait category, whereas a score of ' 3 ' indicates a high affinity to the trait category. Information from the 'taxa by stations' and 'taxa by traits' matrix were then combined to produce a 'trait by station' matrix. To do this, the trait category scores for each taxon present at each station were multiplied by their overall density at each station. To give the same weight to each taxon and each biological trait in further analysis, scores were standardized so that their sum for a given taxon and a given trait equals 1 (or 100\%). 
Table 1 Biological traits and respective categories selected to describe the intertidal benthic community functioning of the Eden estuary from 1999 to 2015.

\begin{tabular}{|c|c|c|}
\hline Biological Traits & Description & Trait Categories \\
\hline $\begin{array}{l}\text { Maximum Size } \\
(\mathrm{mm})\end{array}$ & \multirow{2}{*}{$\begin{array}{l}\text { The trait maximum size and longevity are representative of the } \\
\text { movement of organic matter within the system. } \\
\text { Long-lived and large organisms hold matter within the system } \\
\text { and short-lived small species contributing to higher turnover. } \\
\text { These traits are also indicative of disturbance within the } \\
\text { system. }\end{array}$} & $\begin{array}{l}\text { Small }(<1 \mathrm{~cm}) \\
\text { Small-Medium }(1-2 \mathrm{~cm}) \\
\text { Medium }(3-10 \mathrm{~cm}) \\
\text { Large }(11-20 \mathrm{~cm})\end{array}$ \\
\hline $\begin{array}{l}\text { Adult Longevity } \\
\text { (yr) }\end{array}$ & & $\begin{array}{l}\text { Short }(<2) \\
\text { Medium }(2-5) \\
\text { Long }(>5)\end{array}$ \\
\hline $\begin{array}{l}\text { Growth Form } \\
\text { (morphology) }\end{array}$ & \multirow[t]{2}{*}{$\begin{array}{l}\text { Growth form and feeding method are descriptors of capture, } \\
\text { palatability and movement of energy and matter through the } \\
\text { food web (e.g. carbon). }\end{array}$} & $\begin{array}{l}\text { Articulate A } \\
\text { Bivalved/Turbinate BT } \\
\text { Vermiform Segmented } \\
\text { VS } \\
\text { Tubicolous T } \\
\end{array}$ \\
\hline Feeding method & & $\begin{array}{l}\text { Deposit } \\
\text { Filter/suspension } \\
\text { Opportunist/scavenger } \\
\text { Predator }\end{array}$ \\
\hline $\begin{array}{l}\text { Environmental } \\
\text { Position }\end{array}$ & $\begin{array}{l}\text { Deeper living species are potentially less subjected to } \\
\text { hydrodynamic stress, but are more vulnerable to macroalgae } \\
\text { blooms impacts, hypoxia and anoxia events. }\end{array}$ & $\begin{array}{l}\text { Hyperbenthic HB } \\
\text { Epibenthic EPB } \\
\text { Endobenthic ENB }\end{array}$ \\
\hline $\begin{array}{l}\text { Mobility in } \\
\text { Sediment }\end{array}$ & \multirow[t]{2}{*}{$\begin{array}{l}\text { Movement and development mechanisms capture } \\
\text { energy/materials transfer pathways within the benthos. They } \\
\text { also give insights on potential recovery patterns. }\end{array}$} & $\begin{array}{l}\text { Fixed Tubes FT } \\
\text { Limited Movement LM } \\
\text { Slow free movement } \\
\text { SFM } \\
\text { Free Movement FM }\end{array}$ \\
\hline $\begin{array}{l}\text { Reproductive } \\
\text { method }\end{array}$ & & $\begin{array}{l}\text { Gonochoristic } \\
\text { Hermaphrodite }\end{array}$ \\
\hline $\begin{array}{l}\text { Bioturbation } \\
\text { Functional Type }\end{array}$ & $\begin{array}{l}\text { This trait can both indicate a change in energy and materials } \\
\text { transfer, geochemical cycling-related to environmental change } \\
\text { and the functional effects of such a change. }\end{array}$ & $\begin{array}{l}\text { Surface Modifier SM } \\
\text { Biodiffusor B } \\
\text { Upward conveyor UC } \\
\text { Downward conveyor } \\
\text { DC } \\
\text { Regenerator R } \\
\end{array}$ \\
\hline $\begin{array}{l}\text { Salinity } \\
\text { preference } \\
\text { (ppt) }\end{array}$ & $\begin{array}{l}\text { Describes species distribution depended on the species } \\
\text { preference to salinity. An important environmental filtering } \\
\text { trait in estuaries. }\end{array}$ & $\begin{array}{l}<5 \\
5-20 \\
>20\end{array}$ \\
\hline $\begin{array}{l}\text { Ecological group } \\
\text { (AMBI) }\end{array}$ & $\begin{array}{l}\text { Classifies species according to their tolerance of anthropogenic } \\
\text { disturbance. }\end{array}$ & $\begin{array}{l}\text { Sensitive I } \\
\text { Indifferent II } \\
\text { Tolerant III } \\
\text { Very Tolerant IV } \\
\end{array}$ \\
\hline
\end{tabular}


Following the BTA analysis, community Bioturbation Potential (BPc thereafter) was calculated from infaunal benthic data (i.e. $A=$ abundance, $B=$ biomass and biological traits information of individual species) based on the methodology proposed by Solan et al. (2004). The bioturbation formula is outlined below:

$$
\mathrm{Bp}_{\mathrm{c}}=\sum_{i=1}^{n} \sqrt{\frac{B_{i}}{A_{i}} * A_{i} * A_{i}} * M_{i} * R_{i}
$$

Equation 1

Where $B_{i}$ and $A_{i}$ are the biomass and abundance of a taxon ( $i$ ) in a sample; $M_{i}$ is their standardised score for mobility and $\mathrm{Ri}$ is their standardised score for sediment re-working mode derived according to the standardised scores for mobility and sediment reworking mode listed in Queirós et al. (2013). Overall calculations were conducted for individual species (Bpi) and for the whole community (BPC). This index is an indicator of bioturbation on the functional role of benthic infauna in relation to sediment turnover.

\subsection{Statistical analysis}

Initial statistical analyses regarding the macro-benthic were performed using a nested hierarchical approach (sensu Noss, 1990; Wu \& David, 2002) whereby predefined subsystems (or sites) of the estuary were assessed individually before being combined together to form a larger system. In this way the examination of the relationships between environmental parameters-biodiversity structureecosystem functioning can be better addressed across coastal margins (EPBR, 2011), with different measurement scales providing complementary information about the system. To investigate changes in macro-benthic community structure, multivariate analysis was performed using the permutational multivariate analyses of variance (PERMANOVA) + PRIMER add-on package (Anderson et al., 2008). Prior to analysis, draftsman plots of the values at each site were examined visually to assess whether the values were heavily skewed and, if so, which type of transformation would satisfy the assumption of homogeneity of variances. These plots demonstrated that the data required a square root transformation prior to constricting a similarity matrix based on a Bray-Curtis coefficient to down-weight the contributions of taxa with relatively high values.

To elucidate if changes in the eleven previously calculated univariate biotic indicators were significantly different among sites (upper, central and lower) and between the two years (1999 and 2015), each indicator was subjected to a one-way PERMANOVA. A second approach was also tested for the whole estuary by pooling all the sites together using a one-way pair-wise PERMANOVA design. The null hypothesis that there was no significant difference was rejected if the significance level $(P)$ was $<0.05$. Following the PERMANOVA tests, the same data matrix was subjected to ordination by nMDS (Clarke \& Ainsworth, 1993) in order to visually assess variations in the distribution of community composition. Initially, a general nMDS ordination was carried out taking into account all estuarine sites together followed by a more detailed comparison of nMDS ordinations of each site separately.

Using the same experimental design described above (same number of permutations, permutation method and significance level), the 'traits by station' data matrix resulting from BTA was also subject to PERMANOVA and nMDS in order to statistically and visually assess variations in the distribution of traits composition of both systems. Prior to analysis, the BTA data were square root transformed and a similarity matrix based on Bray-Curtis coefficient was calculated. 


\section{Results}

\subsection{Structural changes in benthic macro-invertebrate assemblages}

Between the pre-management (1999) and post-management (2015) periods, significant $(<0.05$ oneway PERMANOVA) declines in mean density $\left(\mathrm{N} . \mathrm{m}^{-2}\right)\left(-10469 \mathrm{~N} \mathrm{~m}^{-2}\right)$ and mean biomass (-8.01 AFDW g $\mathrm{m}^{-2}$ ) were detected at the estuarine level (Table 2). Declines in mean density, were mainly attributed to population changes in the upper and central sites of the estuary, represented by a significant (< 0.05 one-way PERMANOVA) drop in individuals of $6972\left(\mathrm{~N} \mathrm{~m}^{-2}\right)$ and $3943\left(\mathrm{~N} \mathrm{~m}^{-2}\right)$, respectively. Changes in the overall estuarine biomass were however, concentrated in the central area of the estuary with significant $\left(<0.05\right.$ one-way PERMANOVA) 9.05 (AFDW $\mathrm{g} \mathrm{m}^{-2}$ ) reduction in mean biomass. In contrast to the other two sites, the abundance and biomass of macro-fauna found in the lower estuary increased by 446 individuals, attributing to a 0.55 AFDW $\mathrm{g} \mathrm{m}^{-2}$ increase in mean biomass.

Table 2 Mean density $\left(\mathrm{N} \mathrm{m}^{-2}\right)(\mathrm{N})$ and mean biomass (AFDW $\mathrm{g} \mathrm{m}^{-2}$ ) of all taxa recorded at each site during the study period including one-way PERMANOVA pair-wise post hoc comparisons between years for the whole estuary and each estuarine site using the t-statistic. Values in bold were significant at $(p<0.05)$.

\begin{tabular}{|c|c|c|c|c|c|}
\hline & Site & 1999 & 2015 & Difference & PERMANOVA \\
\hline \multirow[t]{4}{*}{ Mean density $\left(\mathrm{N} \mathrm{m}^{-2}\right)$} & Upper & 12607 & 5635 & -6972 & $<0.05$ \\
\hline & Central & 17614 & 13671 & -3943 & $<0.05$ \\
\hline & Lower & 164 & 610 & 446 & $>0.05$ \\
\hline & All sites & 30385 & 19916 & -10469 & $<0.05$ \\
\hline \multirow[t]{4}{*}{ Mean Biomass (AFDW $\mathrm{g} \mathrm{m}^{-2}$ ) } & Upper & 4.02 & 4.51 & 0.48 & $>0.05$ \\
\hline & Central & 16.74 & 7.69 & -9.05 & $<0.05$ \\
\hline & Lower & 0.46 & 1.02 & 0.55 & $>0.05$ \\
\hline & All sites & 21.24 & 13.23 & 8.01 & $<0.05$ \\
\hline
\end{tabular}

Taxonomic comparisons between the mudflat sites, of the upper and central estuary (Table 3 ) revealed a similarity in four of the five most dominant taxa namely: the errant polychaete Hediste diversicolor, the deposit feeding polychaete Spio filicornis, the molluscan grazer Peringia ulvae and the sub-surface deposit feeding oligochaete Tubificoides benedii. Differences in abundance between the pre- and post-management periods in these sites were characterised by a decrease in density of the oligochaete species Tubificoides benedii and the burrow-dwelling crustacean Corophium volutator in the upper estuary; relative to decreased numbers of the filter-feeding bivalve mollusc Mytilus edulis in the central estuary. Species composition was noticeably different in the lower sites with the presence of the burrow dwelling polychaete Arenicola marina and the motile epibenthic crustaceans Bathyporeia sarsi and Eurydice pulchra, categorising the sandy nature of this site. 
Table 3 List of the 5 most dominant taxa (based on mean density $\left(\mathrm{N} \mathrm{m}^{-2}\right)$ in each site of the Eden Estuary.

\begin{tabular}{llrr}
\hline Upper & Taxa & 1999 & 2015 \\
\hline Hediste (Nereis) diversicolor & Polychaetes & 314 & 271 \\
Spio filicornis & Polychaetes & 1575 & 180 \\
Peringia (Hydrobia) ulvae & Molluscs & 521 & 1646 \\
Tubificoides benedii & Oligochaetes & 5242 & 2307 \\
Corophium volutator & Crustaceans & 4710 & 1029 \\
\hline Central & & & \\
\hline Hediste (Nereis) diversicolor & Polychaetes & 146 & 250 \\
Spio filicornis & Polychaetes & 625 & 125 \\
Mytilus edulis & Molluscs & 1489 & 460 \\
Peringia (Hydrobia) ulvae & Molluscs & 4717 & 4675 \\
Tubificoides benedii & Oligochaetes & 9717 & 1128 \\
\hline Lower & & & \\
\hline Arenicola marina & Polychaetes & 130 & 116 \\
Bathyporeia sarsi & Crustaceans & 78 & 121 \\
Eurydice pulchra & Crustaceans & 28 & 8 \\
Talitrus saltator & Molluscs & 14 & 4 \\
Peringia (hydrobia) ulvae & Molluscs & - & 475 \\
\hline
\end{tabular}

Most of the univariate indices tested suggested a general increase in species richness or evenness of assemblages following the reduction of nutrient inputs to the estuary (Table 4). Significant (1-way PERMANOVA, < 0.05$)$ positive changes at the estuarine level were identified by the species richness, Margalef, Shannon-Wiener, Simpson and Taxonomic Diversity indices at the level of the entire estuary by the post-management period. Spatial analysis also, determined a significant positive change (1-way PERMANOVA, < 0.05 ) in all of the indices except Average Taxonomic Distinctness and Pielou's Index in the upper estuary. In this site Average Taxonomic Distinctness fell slightly, while Pielou's Index remained fairly consistent across all the estuarine sites. In the central estuary significant changes (1-way PERMANOVA, < 0.05) in ecosystem structure were expressed by the Margalef, Shannon-Wiener, Simpson and Total Taxonomic Distinctness indices. No significant differences could be detected from any of the eight indices in the lower site, suggesting a stable environment. 
Table 4 Summary of the structural indicator trends obtained for the Eden estuary after the restoration measure. Arrows in an upward and downward direction represent an increase or decrease in the indicators mean values between each period. Green cells represent an improvement in ecological status, while red cells represent lower ecological status. No significant statistical differences in indices values (Yellow) among years and thus, between periods, showed by $(p>0.05)$.

\begin{tabular}{|c|c|c|c|c|}
\hline \multirow[t]{2}{*}{ Ecological indicator } & \multicolumn{4}{|l|}{ Estuarine sites } \\
\hline & Whole estuary & Upper & Central & Lower \\
\hline Species richness & $\uparrow$ & $\uparrow$ & $p>0.05$ & $p>0.05$ \\
\hline Margalef & $\uparrow$ & $\uparrow$ & $\uparrow$ & $p>0.05$ \\
\hline Shannon-Wiener & $\uparrow$ & $\uparrow$ & $\uparrow$ & $p>0.05$ \\
\hline Pielou & $p>0.05$ & $p>0.05$ & $p>0.05$ & $p>0.05$ \\
\hline Simpson & $\downarrow$ & $\downarrow$ & $\downarrow$ & $p>0.05$ \\
\hline Taxonomic Diversity & $\uparrow$ & $\uparrow$ & $p>0.05$ & $p>0.05$ \\
\hline Taxonomic Distinctness & $p>0.05$ & $\downarrow$ & $p>0.05$ & $p>0.05$ \\
\hline Total Taxonomic Distinctness & $p>0.05$ & $\uparrow$ & $\uparrow$ & $p>0.05$ \\
\hline
\end{tabular}

Permutations from both the M-AMBI and IQI indexes, considered the benthic habitat quality of the Eden to be 'high' at the estuarine level across both periods (Table 5). At the site level, both indices recognised an improvement in habitat quality from poor to moderate for the central estuary after catchment alterations. In contrast to $\mathrm{M}-\mathrm{AMBI}$, the IQI index could not detect a change in ecological status in the upper area of the estuary. As with the univariate indicators, neither index could distinguish any change in habitat quality in the lower estuary.

Table $5 \mathrm{M}$-AMBI and Infaunal Quality Index (IQI) EQR scores from The Eden estuary 1999-2015. Different colours represent environmental status; High (Dark green), Good (light green), Moderate (Yellow), Poor (Purple).

\begin{tabular}{|c|c|c|c|c|}
\hline \multicolumn{3}{|c|}{ M-AMBI } & \multicolumn{2}{|c|}{ IQI } \\
\hline Site & & & & 2015 \\
\hline Whole & High & High & High & High \\
\hline Upper & Good & High & Good & Good \\
\hline Central & Poor & High & Moderate & Good \\
\hline Lower & Good & Good & Good & Good \\
\hline
\end{tabular}

\subsection{Biological traits analysis}

When considering the biological traits composition data from all of the estuarine sites together, a significant difference was detected between the pre- and post-management periods in inter-tidal benthic community functioning (one-way PERMANOVA, $p<0.05$ ). Significant changes were also detected (one-way PERMANOVA, $p<0.05$ ) in the upper and central estuarine sites. These trends are clearly seen in the in the nMDS ordinations coded for both the temporal factor 'year' and spatial factor 'site' (Figure 2) with the temporal segregation of central zone communities particularly apparent. 
Figure 2 nMDS ordination plots of biological traits composition data considering data from all estuarine sites together over the time periods defined by the intervention under study: premanagement 1999 (Triangles), and post-management 2005 (Circles).

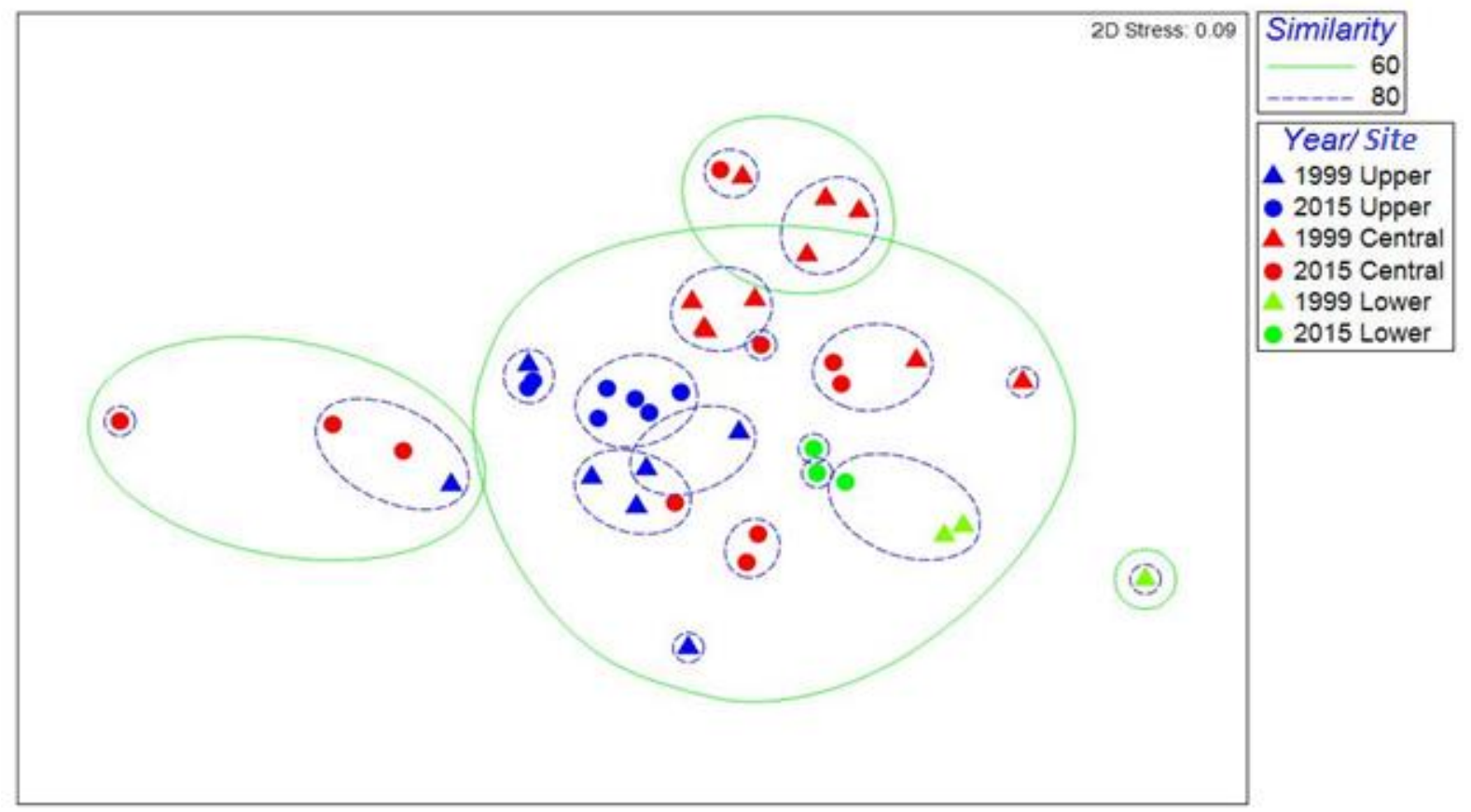

With regard to the main biological traits categories describing the Eden estuary as a whole (Figure 3), spatial distributions of different body size categories changed between the pre and postmanagement periods, with a graduation towards a more evenly distributed size structure across the estuary. In 2015 , very small $(<1 \mathrm{~cm})$ and large $(11-20 \mathrm{~cm})$ individuals increased in contribution to overall biomass concurring with a fall in medium $(3-10 \mathrm{~cm})$ sized individuals. Species with a medium (2-5 years) life span were only found in the 2015 period. There was also a simultaneous increase (15 $\%)$ in long lived individuals during this period. Tubicolous species only contributed to $<2 \%$ of the total ecological functioning of the estuary across both periods. Between the periods, there was a general increase in bivalve or turbinate species relative to a decline in articulate and vermiform segmented species, with the latter dominating the morphology of the estuary. Species with a hermaphroditic reproductive technique contributed most $(\sim 70 \%)$ to the biomass of the system during the 1999 period, followed by a shift to a system where individual organisms were more often gonochorous ( $60 \%)$. Deposit feeding individuals were the most representative feeding traits expressed in the Eden estuary (> $60 \%$ in both scenarios). Following management interventions there was a decrease in deposit feeders and an increase in the three other resource capturing methods: filter/ suspension, opportunistic/scavenger and predators. Slow free moving taxa dominated the biomass of both periods, while sedentary tube dwelling taxa were absent from the pre-management period. During the contemporary period, limited and free moving taxa increased in eminence. Distributions of taxa across the sediment-water interface were almost equivalent between the two periods, with a slight increase (5\%) in hyperbenthic species during the 2015 period. Biodiffusing taxa were the most influential taxa in facilitating geochemical cycling processes, during both periods. Contributions to ecological functioning of surficial modifying taxa, almost doubled (from 20 to 40\%) during the 2015 period. Tolerance to differing salinity regimes at the estuarine level, was largely analogous between the two periods, suggesting no substantial changes in species taxa distributions 
due to the increasing influence of freshwater inputs. The vast majority (>95\%) of taxa across both periods were classified as tolerant or very tolerant to disturbance. Following management measures (2015), there was an approximately $30 \%$ reduction in very tolerant species classified.
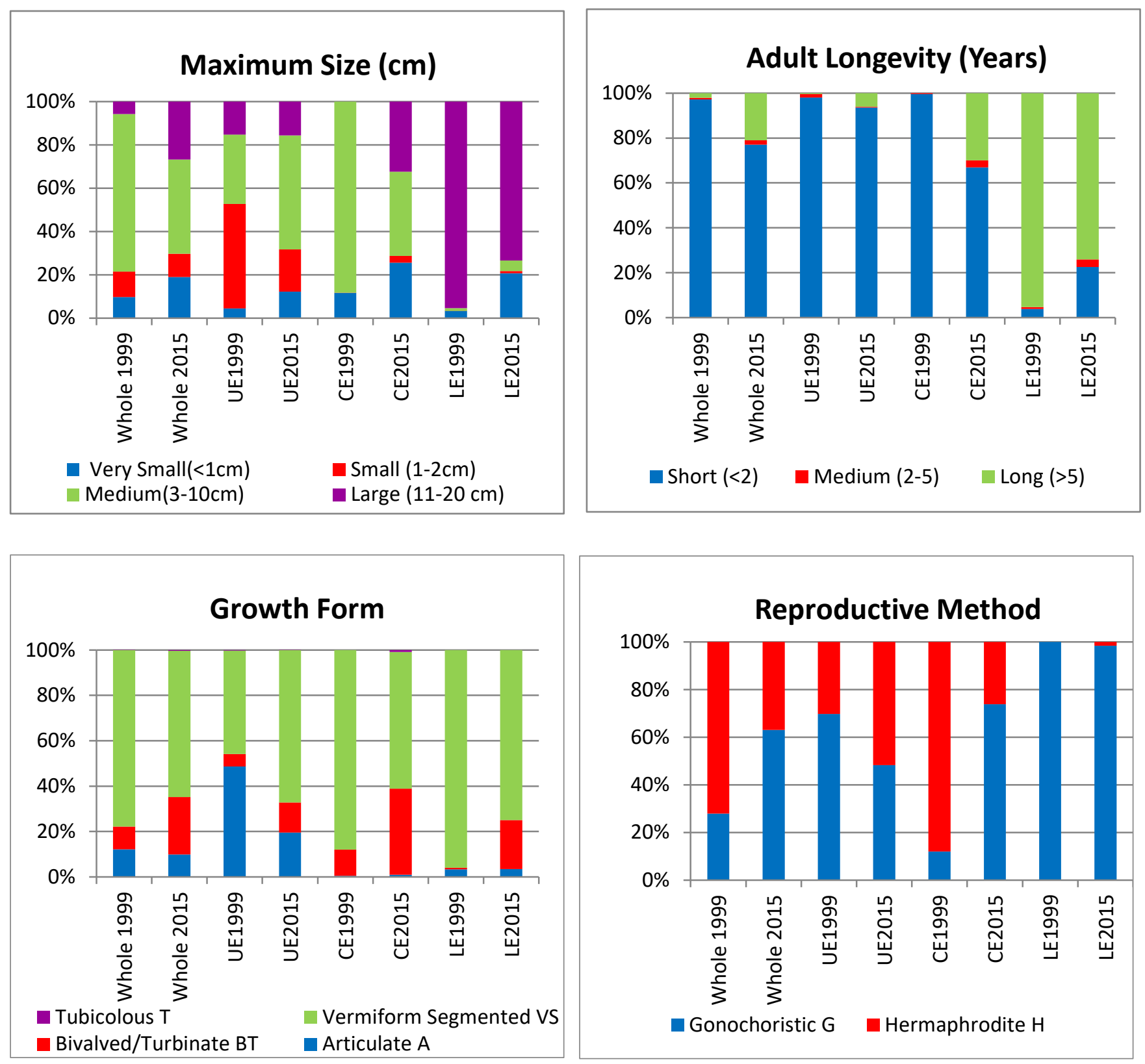

Figure 3 Biological traits patterns for the whole Eden estuary and each site upper (UE), central (CE) and lower (LE) over the study period (1999-2015). 

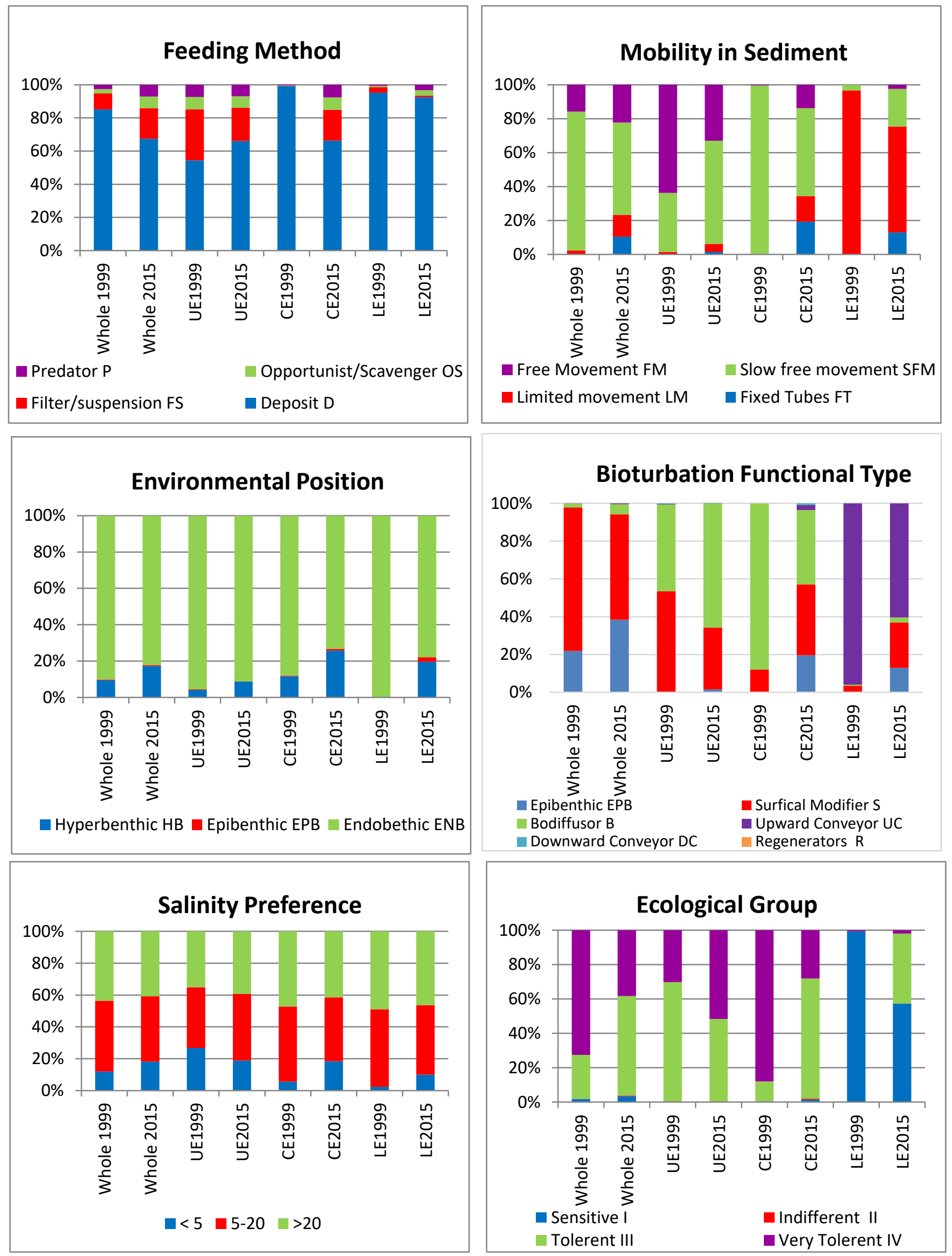

Figure 3 (continued) Biological traits patterns for the whole Eden estuary and each site upper (UE), central (CE) and lower (LE) over the study period (1999-2015). 
Considering assessments of each site individually, the upper estuary was characterised by a graduation towards short lived, free and slow moving taxa comprised of medium $(3-10 \mathrm{~cm})$ sized individuals. Articulate taxa were particularly abundant in the upper estuary, but showed a relative $>$ $30 \%$ decline in biomass. Bivalve and turbinate species increased in biomass across all three sites between the time periods. Biodiffusor and upward conveying benthic species co-dominated the upper estuarine site with a successive increase in the latter.

Short lived species dominated the ecological functioning of the central site of the estuary, but large $(11-20 \mathrm{~cm})$ and small $(1-2 \mathrm{~cm})$ individuals were completely absent from the central estuary during the pre-management period. A shift from hermaphroditic to a gonchoristic reproductive lifestyle strategy was also expressed in the central site, while the opposite pattern was depicted in the upper reaches. Complete supremacy of slow free moving species in the central estuary, was fragmented by an increased presence of free moving and more solitary species in the post-management period. Similar biturbation trait compositions were expressed in the central estuary, prior to an insurgence of surficial modifying and biodifusive taxa. In the sandy lower estuary, long lives species exhibited the greatest temporal biomass, predominated by large $(11-20 \mathrm{~cm})$ individuals such as the sandworm Arenicola marina. Limited mobility species were replaced by free moving and tube dwelling species in the lower estuary and geochemical processes were mediated by a prevalence of downward conveying species.

Tolerance to salinity remained relatively constant and was comparable to the patterns of the estuary as a whole, but the finer resolution suggested a greater proportion of species with high tolerances to low salinity $(<5 \mathrm{ppm})$ to be present in the upper site (at the river-estuarine interface). In converse, a high proportion species with a preference for high salinity (>20ppm) were found at the mouth of the estuary. Habitat preference and sediment reworking modes followed the trends described for the estuary as a whole across all sites. Tolerant and very tolerant taxa were the mainstay of the upper and central sites, with the former recording an increase in the proportion of very tolerant individuals, parallel to the opposite trend in the central estuary. Contrastingly, sensitive species were the largest group in the lower estuary with > 99\% representation in the 1999 period. This was followed by an influx ( $40 \%)$ of more tolerant individuals.

\subsection{Bioturbation potential (BPc) results}

BPc calculations for the estuary as a whole, illustrated a general increase in biogenic functioning from 318 to 438 BPcs following the post-management initiatives (Figure 4). When the resolution was increased to the level of individual sites, relative benthic functioning in 2015 was highest (300 BPcs) in the transitional upper site and the lowest (51 BPcs) in the sandy lower site of the estuary. 


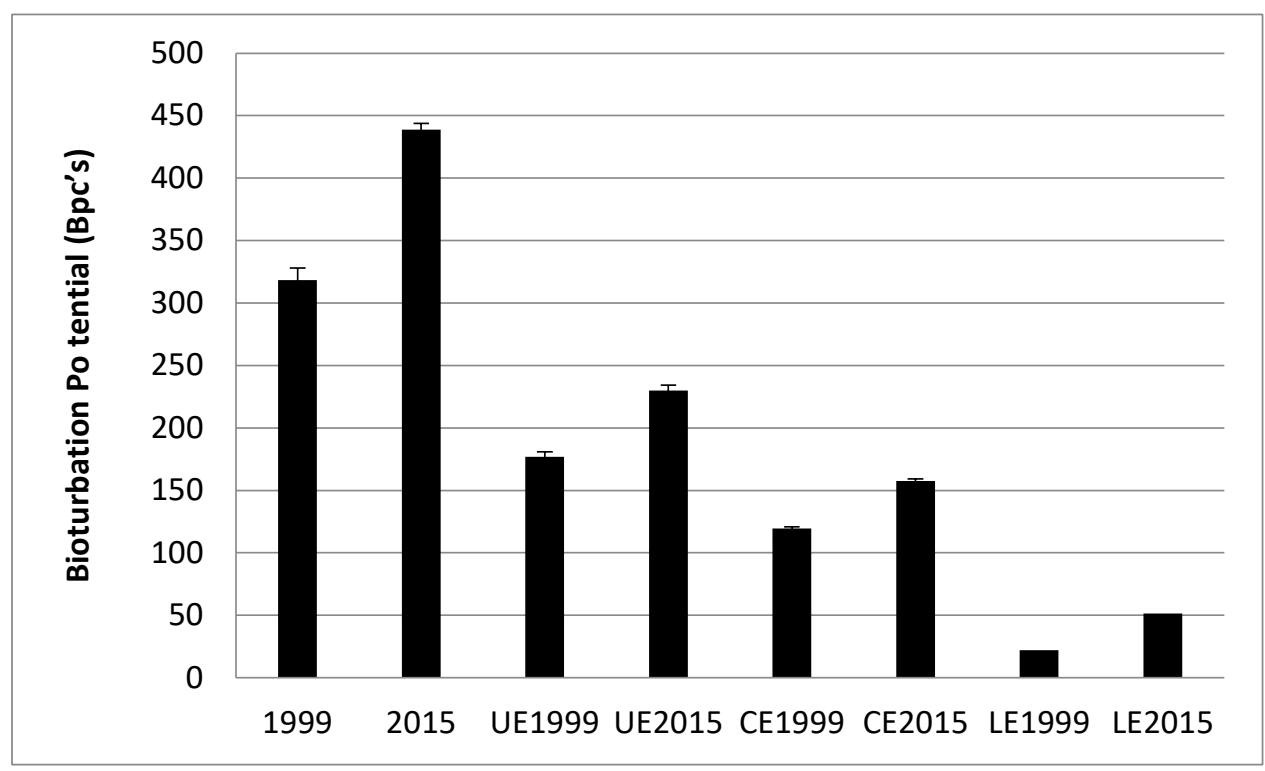

Figure 4 Bioturbation potential (BPc) values for the Eden estuary by year (1999-2015) and site based on equal sample sizes; upper (UE), central (CE) and lower (LE) with 95\% confidence intervals.

\section{Discussion}

\subsection{Response of macro-benthic communities toward restoration}

Following the implementation of nutrient restoration measures in 2003, macro-benthic community structure between the pre- (1999) and post- (2015) management periods differed temporally and spatially. Generally, most of the structural indicators tested (e.g. Margalef, Shannon-Wiener, Simpson) were able to capture useful information about the state of the inter-tidal macro-benthic community with regards to decreasing nutrient regimes. In contrast, Pielou's Index and Taxonomic Diversity measures seemed to have been the least efficient in reflecting the recovery trajectory of the environmental conditions under this investigation. When considered spatially, many of the diversity and evenness indicators suggested positive changes at the level of the whole system, but our nested hierarchical approach revealed that only in the upper and central estuary were there significant compositional changes. This specificity seems important from a local ecological perspective as previous assessments of the macro-benthic structure of the estuary have mainly focused on the central site (e.g. Chocholek, 2013). Such approaches also fit well with an WFD monitoring framework, with the need to account for different sites inherent natural variability to environmental conditions (Teixeira et al., 2008) all the while exemplifying the need for an ecosystem-based approach to management that considers the entire ecosystem.

In the upper site, all structural indicators (with the exception of Pielou's Index) were able to detect significant differences between years and thus, between the time periods. Most indicators with the exception of Average Taxonomic Distinctness (reflected changes in the community structure and composition consistent with an indication of a better ecological condition in this estuarine site. Taken in context, these indicators based upon measures of equitability and dominance were apparently, reflecting the large decrease in abundance of four of the five most numerous taxa and the increase in greater richness or potential of the community to respond to future perturbations. In the central estuary, as species density and biomass fell between the pre- and post-management periods, the structural indicators: Margalef, Shannon-Wiener and Simpson's, successfully calculated 
significant temporal changes in the evenness and dominance of the community. Large negative changes in the indicator species Tubificoides benedii, in the upper and central estuary, point towards recovery from anthropogenic enrichment, while an increase in overall species richness/diversity has likely lead to an increase in the functional redundancy (Hooper et al., 2005) and therefore resilience of the whole system. A final assessment of the geomorphologicaly different lower estuary showed this site to be a highly stable environment with no significant variations detected by any of the compositional or structural indicators. Generally, the number of species abundance and species richness present in this site were found to be low and spatially uniform, characteristic of unimpacted sand dominated transitional environments (e.g. McLachlan \& Brown, 2006).

Both the ecological indices M-AMBI and IQI were also able to successfully track the ecological trends in each time series, despite the EQRs showing different temporal and spatial patterns. Comparatively, IQI was found to be a more conservative index than M-AMBI, concurring with recent studies (Kröncke \& Reiss, 2010; Kennedy et al., 2011) suggesting IQI to be less sensitive to climatic and natural variation than M-AMBI. This is an important consideration when analysing for significant change in ecological status, and the future purpose of devising UK specific EQRs.

As many of the operative structural indicators tested form the mainstay of many environmental monitoring programmes, both in the UK (e.g. IQI) and in Europe (e.g. M-AMBI) these results are encouraging for assessments made in transitional environments, which have been traditionally challenging to monitor (Dauvin, 2007; Neto et al., 2010; Elliott et al., 2011). Having this knowledge, it becomes theoretically possible to predict in advance the behaviour, and consequently, the ability of an ecological indicator to measure and detect changes in ecological conditions (Pinto, 2009; Veríssimo et al., 2012a). It should be taken into consideration however, that environmental context is an extremely important determinant of how marine communities respond to stressors (Bulling et al., 2008; Crain et al., 2008; Thrush et al., 2008; Godbold et al., 2011; Donohue, 2013) and that even small shallow-water estuarine systems can be highly heterogeneous environments. Consequently, it is important to consider that the observed changes in the post-management period could be a result of other forms of anthropogenic stress and/or management interventions in agreement with the "Estuarine Quality Paradox" (Elliott \& Quintino, 2007), Fortunately, due to its small size and relative distance from major populations, management interventions on the Eden (with the exception of the NVC legislation) have been very minor over the last few decades (Scottish Natural Heritage, 2006) making it easier to disentangle the complex relationships associated with the investigation of multiple stressor interactions. Natural climate variability such as increased river flows is more likely to have influenced changes in the macro-benthic communities (Chocholek, 2013), although evidence from the salinity preference trait suggested no substantial changes in species tolerance to increasing river flow and therefore osmotic stress. 


\subsection{Relationship between macro-invertebrate biological traits and sea bed functioning in the Eden Estuary.}

Considered at the estuarine level, the results of the BTA showed quite similar trait distributions between the pre- (1999) and post- (2015) management periods, initially suggesting at least when considered as a whole, the estuary is continuing to function in a similar manner under the influence of nutrient reductions. Trait diversification, however, increased between the periods suggesting an increased overlap in traits and therefore the functional redundancy of the system to buffer against future changes (Hooper et al., 2005).

At the level of individual sites, the results of the BTA showed quite similar trait distributions within the lower estuary, whereas, the trait distributions at the central and upper most part of the estuary were considered to be significantly different, suggesting the observed structural changes in community composition had influenced ecosystem functioning within these sites. Changes of traits in relation to patterns of environmental disturbance were reflected by several traits in the post management period, with the percentage of individuals being 'larger', 'longer lived' and 'hyperbenthic' all increasing. Generally these traits are generally cited as being indicative of a less stressed environment (Philippart, 1998; Basset et al., 2004)

Impacts on traits pertaining to the assimilation and cycling of matter were most prominent within the central area of the estuary, with a shift from slow free moving deposit-feeding benthos to a more heterogeneous community composed of more sedentary filter-feeding and mobile scavenger/predator species. These changes echo the fall in dominance of the deposit feeding oligochaete, Tubificoides benedii, and rise in numbers of the filter-feeding bivalve, Cerastoderma edule. As these species represent a significant proportion of the organic carbon within the estuary, such significant changes in numbers and by proxy traits is likely to have important consequences on many ecosystem processes which are inherently linked to a number of ecosystem services such as carbon sequestration/storage (Beaumont et al., 2014) and nutrient/waste remediation (Watson et al., 2016). For example, following nutrient disturbances Cerastoderma edule has been shown (e.g. Kang et al., 1999; Cesar \& Frid, 2012) to revert from a diet consisting of material from the benthos to more material consisting from the water column. Therefore, in comparison to the high nutrient periods of 1999, trait distributions of the central estuary imply there is a greater degree of benthicpelagic coupling taking place, which has implications for the transfer and processing of nutrients and carbon within the sediments (Loo \& Rosenberg, 1996).

Considering the movement of material once it enters the benthos, BPc results for the entire estuary indicate an increase in the potential biogenic functioning of the sediments relative to the premanagement period, with the greatest capacity for sediment turn over estimated in the upper estuary. Based on the classification of marine invertebrate infauna into bioturbation groups sensu (Queiros et al., 2013) it was also apparent different sites displayed different traits underlying the ecosystem processes of bioturbation and bioirrigation. In the muddy upper and central sites, community traits trended towards biodiffusers (whose activities result in a constant and random diffusive transport of particles over short distances) and upward conveying (that actively transport sediment from the sediment surface) reworking types, while the lower estuary was dominated by species with downward (that actively transport sediment to the sediment surface) conveying traits. Additionally, the trait salinity preference suggested no substantial changes in species tolerance 
across any of the sites between the sampling periods. This is particularly important result regarding the upper estuary, where changes in flow dynamics and salinity are most likely to impact organisms.

Generally, both Biological Traits Analysis and community bioturbation potential (BPc) seemed effective in highlighting the general picture regarding the functioning of the benthic communities, suggesting a substantial increase in benthic functioning under decreasing nutrient stress. When the functional traits of macro-fauna considered in the BPc index (i.e. mobility and reworking mode) were combined with BTA, this also allowed a greater visualisation of the influence of specific traits and how they were likely to affect ecological functions. Care should be taken in interpretation of our BPC results however, as the empirical relationships reported do not provide information about which mechanistic attributes of bioturbation as a community process influence sedimentary systems, other than the functional traits of macro-fauna considered in the index (Queirós et al., 2015). We therefore acknowledge that a focus on acquiring accompanying metrics of functioning (e.g. sediment biogeochemistry, secondary production) aligned with traits information would significantly improve our ability to determine both the identity and importance of effects traits for specific ecosystem processes relating to carbon and nutrient cycling.

\section{Conclusions}

Amid concerns that estuarine ecosystems are becoming increasing degraded (Halpern et al., 2008), restoration ecologists world-wide have begun to establish the relationships between drivers, their pressures (stressors) and impacts (effects) in order to provide coastal managers with a scientific basis upon which to assist in the recovery of an ecosystem that has been degraded, damaged, or destroyed (Atkins et al., 2011; Pinto et al., 2013; Patrício et al., 2016). In the case of eutrophication or increased nutrient stress, the response of ecosystems to nutrient abatement is not always clear, with many estuarine systems failing to return to their reference status upon nutrient reductions (Durate et al., 2009). Therefore, understanding the recovery trajectory of individual systems and the metrics that can describe such responses is of direct relevance to many scientific and regulatory frameworks. Moreover, although the response of macro-benthic communities to restoration actions is often well-known, there is a lack of relevant temporal studies that consider a multiple spatial scales approach (Ansari et al., 2017) and only a limited number of studies (e.g. Veríssimo et al., 2012b; van der Linden et al., 2012; Krumhansl et al., 2017) that have used functional metrics such as BTA or BPc to assess management measures in temperate estuaries.

In the system studied here, the shifts in the vast majority of the structural and functional indicators were generally consistent with recovery trajectories described for other nutrient disturbed systems (Pearson \& Rosenberg, 1978; Van Kleef et al., 2006; Cardoso et al., 2007; Bolam \& Eggleson, 2014) and were very consistent with patterns in the ecological quality indices used (AMBI and IQI). This supports the usefulness of such approaches for assessing the recovery patterns of transitional benthic systems. Specifically, the fact that the functional indices largely corroborate the results of the structural and multi-metric indices is a promising indication, suggesting that a more traditional structural framework (e.g. as employed by the Water Framework Directive) could be supplemented with information about the ability of an ecosystem to function and ultimately provide ecosystem services.

These findings are also of direct importance to local management, suggesting that the level of intervention in the form of the nitrate vulnerable zone (NVZ) was sufficient in this case to produce a noticeable positive impact on the receiving benthic biota over a relatively short timescale. These findings are synonymous with other positive outcomes of NVZ legislation in other small estuaries in the UK such as the Ythan (Raffaelli, 2011), but contrast with similar water quality improvement 
efforts in many larger groundwater-dominated catchments (Burt et al., 2011) where nutrient levels have remained obstinately high due to the biochemical lag times (often decades) associated with groundwater reservoirs (Hamilton, 2011). Continued monitoring and research of the Eden estuary is therefore prudent, with increased anthropogenic activity likely to be a key to feature for management within the foreseeable future. For instance, increased infrastructural development underway in the upper reaches of the estuary at the Guardbridge Paper Mill site, including a new 'state-of-the-art' biomass facility, could have unforeseen impacts on the bio-physical properties of the estuary (Prophet, 2015). As such, this study highlights the potential of re-analysing data sets from earlier research programmes and it is likely that the comprehensive large scale monitoring information provided in this study is another extremely valuable baseline with which future studies can be compared against in order to prevent future degradation and to maintain the prevailing ecological conditions of the estuary. Although there is likely uncertainty in only comparing two time periods in this study, due the inherent lack of data available at large spatial scales, the analysis developed here can still be used to visualise potential directions of change and thus inform about potential consequences and support local planning of management actions.

As a final point, the focus of this study was principally on only one component of the estuarine environment, namely the benthic invertebrates. However, research on the relationship between estuarine biodiversity and ecosystem functioning is entering a new phase, accepting that impacts on biodiversity generally involves reductions and changes in species across different trophic levels simultaneously (Raffaelli, 2006). The evaluation of other biological quality elements (especially primary producers such as macrophytes, benthic fish and waterbirds) is consequently recommended as well as, the use of long-term data sets in order to better understand the effectiveness of the restoration measure undertaken.

\section{Acknowledgments}

This work was supported by the EU grant MAS3-CT97-0158 'BIOPTIS' and was funded with support from the Biodiversity and Ecosystem Service Sustainability (BESS) programme [NERC Grant Ref: $\mathrm{NE} / \mathrm{K} 501244 / 1]$. BESS is a six-year programme (2011-2017) funded by the UK Natural Environment Research Council (NERC) and the Biotechnology and Biological Sciences Research Council (BBSRC) as part of the UK's Living with Environmental Change (LWEC) programme. DMP also received funding from the MASTS pooling initiative (The Marine Alliance for Science and Technology for Scotland) and their support is gratefully acknowledged. MASTS is funded by the Scottish Funding Council (grant reference HR09011) and contributing institutions. The authors would like to thank Andrew Blight, Irvine Davidson, Jack Maunder and Eugenia Pasanisi for their aid in GPS positioning and help with the collection of macro-faunal data from the Eden estuary. 


\section{References}

Anderson, M. J., Gorley, R. N., and Clarke, K. R. (2008). PRIMER+ for PERMANOVA: Guide to Software and Statistical Methods. 214. Primer-e: Plymouth, UK.

Ansari, K.G.M.T., Pattnaik, A.K., Rastogi, G. and Bhadury, P., (2017). Multiple spatial scale analysis provide an understanding of benthic macro-invertebrate community structure across a lagoonal ecosystem. Wetlands, 37(2), pp.277-287.

Atkins, J.P., Burdon, D., Elliott, M. and Gregory, A.J., (2011). Management of the marine environment: integrating ecosystem services and societal benefits with the DPSIR framework in a systems approach. Marine pollution bulletin, 62(2), pp.215-226.

Balvanera, P., Pfisterer, A. B., Buchmann, N., He, J. S., Nakashizuka, T., Raffaelli, D., and Schmid, B. (2006). Quantifying the evidence for biodiversity effects on ecosystem functioning and services. Ecology letters, 9(10), pp.1146-1156.

Basset, A., Sangiorgio, F. and Pinna, M., (2004). Monitoring with benthic macroinvertebrates: advantages and disadvantages of body size descriptors. Aquatic Conservation: Marine and Freshwater Ecosystems, 14(S43-S58).

Beaumont, N.J., Jones, L., Garbutt, A., Hansom, J.D. and Toberman, M., (2014). The value of carbon sequestration and storage in coastal habitats. Estuarine, Coastal and Shelf Science, 137, pp.32-40.

Bennett, T.L. and McLeod, C.R., (1998). East Scotland (Duncansby Head to Dunbar) (MNCR Sector 4). In: Marine Nature Conservation Review. Benthic Marine Ecosystems of Great Britain and the North-East Atlantic, Hiscock K (ed.). Joint Nature Conservation Committee: Peterborough, pp.123154.

Biles, C.L., Paterson, D.M., Ford, R.B., Solan, M. and Raffaelli, D.G., (2002). Bioturbation, ecosystem functioning and community structure. Hydrology and Earth System Sciences Discussions, 6(6), pp.999-1005

Bolam, S.G. and Eggleton, J.D., (2014). Macrofaunal production and biological traits: spatial relationships along the UK continental shelf. Journal of Sea Research, 88, pp.47-58.

Borja, A. and Dauer, D.M., (2008). Assessing the environmental quality status in estuarine and coastal systems: comparing methodologies and indices. Ecological indicators, 8(4), pp.331-337.

Borja, Á., Elliott, M., Carstensen, J., Heiskanen, A.S. and van de Bund, W., (2010). Marine management-towards an integrated implementation of the European Marine Strategy Framework and the Water Framework Directives. Marine pollution bulletin, 60(12), pp.2175-2186.

Borja, A., Mader, J. and Muxika, I., (2012). Instructions for the use of the AMBI index software (Version 5.0). Revista de Investigación Marina, AZTI-Tecnalia, 19(3), pp.71-82.

Borja, A., Ranasinghe, A. and Weisberg, S.B., (2009). Assessing ecological integrity in marine waters, using multiple indices and ecosystem components: challenges for the future. Marine Pollution Bulletin, 59(1-3), pp.1-4.

Bremner, J., (2008). Species' traits and ecological functioning in marine conservation and management. Journal of Experimental Marine Biology and Ecology, 366(1-2), pp.37-47. 
Bremner, J., Paramor, O.A.L., Frid, C.L.J., (2006a). Developing a methodology for incorporating ecological structure and functioning into designation of Special Areas of Conservation (SAC) in the 012 nautical mile zone, Report to English Nature. Inductively Coupled Plasmas in Analytical Atomic Spectrometry. University of Liverpool, Liverpool. pp153.

Bremner, J., Rogers, S.I. and Frid, C.L.J., (2003). Assessing functional diversity in marine benthic ecosystems: a comparison of approaches. Marine Ecology Progress Series, 254, pp.11-25.

Bremner, J., Rogers, S.I. and Frid, C.L.J., (2006b). Methods for describing ecological functioning of marine benthic assemblages using biological traits analysis (BTA). Ecological Indicators, 6(3), pp.609622.

Brey, T. (2001). Population dynamics in benthic invertebrates. A virtual handbook. www.awibremerhavende/Benthic/Ecosystem/FoodWeb/Handbook/main Alfred Wegener Institute for Polar and Marine Research, Germany.

Bulling, M.T., Solan, M., Dyson, K.E., Hernandez-Milian, G., Luque, P., Pierce, G.J., Raffaelli, D., Paterson, D.M. and White, P.C., (2008). Species effects on ecosystem processes are modified by faunal responses to habitat composition. Oecologia, 158(3), pp.511-520.

Burt, T.P., Howden, N.J.K., Worrall, F., Whelan, M.J. and Bieroza, M., (2011). Nitrate in United Kingdom rivers: policy and its outcomes since 1970. Environmental Science and Technology, 45, pp. 175-81.

Cardinale, B.J., Srivastava, D.S., Duffy, J.E., Wright, J.P., Downing, A.L., Sankaran, M. and Jouseau, C., (2006). Effects of biodiversity on the functioning of trophic groups and ecosystems. Nature, 443(7114), pp.989.

Cardoso, P.G., Bankovic, M., Raffaelli, D. and Pardal, M.A., (2007). Polychaete assemblages as indicators of habitat recovery in a temperate estuary under eutrophication. Estuarine, Coastal and Shelf Science, 71(1-2), pp.301-308.

Cesar, C.P. and Frid, C.L., (2012). Benthic disturbance affects intertidal food web dynamics: implications for investigations of ecosystem functioning. Marine Ecology Progress Series, 466, pp.3541.

Chevenet, F., Doléadec, S., and Chessel, D. (1994). A fuzzy coding approach for the analysis of longterm ecological data. Freshwater Biology, 31(3), pp.295-309.

Chocholek, M., (2013). The impacts of climate change on estuarine ecosystems: a case study on the Eden estuary, Fife, Scotland (Doctoral dissertation, University of St Andrews).

Clarke, K.R. and Ainsworth, M., (1993). A method of linking multivariate community structure to environmental variables. Marine ecology progress series, pp.205-219.

Clarke, K.R. and Warwick, R.M., (1999). The taxonomic distinctness measure of biodiversity: weighting of step lengths between hierarchical levels. Marine Ecology Progress Series, pp.21-29.

Clarke, K.R. and Warwick, R.M., (2001). A further biodiversity index applicable to species lists: variation in taxonomic distinctness. Marine ecology Progress series, 216, pp.265-278.

Clarke, K.R., Gorley, R.N., Somerfield, P.J., Warwick, R.M., (2014). Change in marine communities: an approach to statistical analysis and interpretation 3rd edition. PRIMER-E Ltd, Plymouth, UK. 
Clelland, B. E. (1997). The Eden Estuary: A review of its ecological and conservation interest, with particular reference to water quality. In: Coastal zone topics, 3. Estuaries of Central Scotland. McLusky DS, editor. Estuarine and Coastal Sciences Association, Aberdeen.

Crain, C.M., Kroeker, K. and Halpern, B.S., (2008). Interactive and cumulative effects of multiple human stressors in marine systems. Ecology letters, 11(12), pp.1304-1315.

Crowe, T.P. and Russell, R., (2009). Functional and Taxonomic Perspectives of Marine Biodiversity. In Marine Hard Bottom Communities (pp. 375-390). Springer, Berlin, Heidelberg.

Dauvin, J.C., (2007). Paradox of estuarine quality: benthic indicators and indices, consensus or debate for the future. Marine Pollution Bulletin, 55(1-6), pp.271-281.

Donohue, I., Petchey, O.L., Montoya, J.M., Jackson, A.L., McNally, L., Viana, M., Healy, K., Lurgi, M., O'Connor, N.E. and Emmerson, M.C., (2013). On the dimensionality of ecological stability. Ecology Letters, 16(4), pp.421-429.

Duarte, C.M., Borja, A., Carstensen, J., Elliott, M., Krause-Jensen, D. and Marbà, N., (2015). Paradigms in the recovery of estuarine and coastal ecosystems. Estuaries and Coasts, 38(4), pp.12021212.

Duarte, C.M., Conley, D.J., Carstensen, J. and Sánchez-Camacho, M., (2009). Return to Neverland: shifting baselines affect eutrophication restoration targets. Estuaries and Coasts, 32(1), pp.29-36.

Duck, R.W. and Wewetzer, S.F., (2001). Impact of frontal systems on estuarine sediment and pollutant dynamics. Science of the total environment, 266(1-3), pp.23-31.

Duck, R.W., McManus, J. and Diez, J.J., (1995). Comparative study of two largely infilled estuaries: the Eden Estuary (Scotland) and the Ria de Foz (Spain). Netherland Journal of Aquatic Ecology, 29(34), pp.203-210.

Elliott, M. and De Jonge, V.N., (2002). The management of nutrients and potential eutrophication in estuaries and other restricted water bodies. In Nutrients and Eutrophication in Estuaries and Coastal Waters (pp. 513-524). Springer, Dordrecht.

Elliott, M. and Quintino, V., (2007). The estuarine quality paradox, environmental homeostasis and the difficulty of detecting anthropogenic stress in naturally stressed areas. Marine Pollution Bulletin, 54(6), pp.640-645.

Elliott, M., Burdon, D., Hemingway, K.L. and Apitz, S.E., (2007). Estuarine, coastal and marine ecosystem restoration: confusing management and science-a revision of concepts. Estuarine, Coastal and Shelf Science, 74(3), pp.349-366.

EPBR (European Platform for Biodiversity Research), (2011). Recommendations of the meeting of the European Platform for Biodiversity Research Strategy concerning Ecosystem Services, Budapest.

Ford, R.B. and Honeywill, C., (2002). Grazing on intertidal microphytobenthos by macrofauna: is pheophorbide aa useful marker?. Marine Ecology Progress Series, 229, pp.33-42.

Godbold, J.A., Bulling, M.T. and Solan, M., (2011). Habitat structure mediates biodiversity effects on ecosystem properties. Proceedings of the Royal Society of London B: Biological Sciences, 278(1717), pp.2510-2518. 
Hamilton, S.K., (2011). Biogeochemical time lags may delay responses of streams to ecological restoration. Freshwater Biology, 57(s1), pp.43-57.

Hooper, D.U., Chapin, F.S., Ewel, J.J., Hector, A., Inchausti, P., Lavorel, S., Lawton, J.H., Lodge, D.M., Loreau, M., Naeem, S. and Schmid, B., (2005). Effects of biodiversity on ecosystem functioning: a consensus of current knowledge. Ecological monographs, 75(1), pp.3-35.

Howarth, R., Chan, F., Conley, D.J., Garnier, J., Doney, S.C., Marino, R. and Billen, G., (2011). Coupled biogeochemical cycles: eutrophication and hypoxia in temperate estuaries and coastal marine ecosystems. Frontiers in Ecology and the Environment, 9(1), pp.18-26.

Howarth, R.W. and Marino, R., (2006). Nitrogen as the limiting nutrient for eutrophication in coastal marine ecosystems: evolving views over three decades. Limnology and Oceanography, 51(1part2), pp.364-376.

Kang, C.K., Sauriau, P.G., Richard, P. and Blanchard, G.F., (1999). Food sources of the infaunal suspension-feeding bivalve Cerastoderma edule in a muddy sandflat of Marennes-Oléron Bay, as determined by analyses of carbon and nitrogen stable isotopes. Marine Ecology Progress Series, pp.147-158.

Kennedy, R., Arthur, W. and Keegan, B.F., (2011). Long-term trends in benthic habitat quality as determined by Multivariate AMBI and Infaunal Quality Index in relation to natural variability: A case study in Kinsale Harbour, south coast of Ireland. Marine pollution bulletin, 62(7), pp.1427-1436.

Kennish, R., Williams, G.A. and Lee, S.Y., (1996). Algal seasonality on an exposed rocky shore in Hong Kong and the dietary implications for the herbivorous crab Grapsus albolineatus. Marine Biology, 125(1), pp.55-64.

Kröncke, I. and Reiss, H., (2010). Influence of macrofauna long-term natural variability on benthic indices used in ecological quality assessment. Marine Pollution Bulletin, 60(1), pp.58-68.

Krumhansl, K., Jamieson, R. and Krkosek, W., (2017). Using species traits to assess human impacts on near shore benthic ecosystems in the Canadian Arctic. Ecological indicators, 60, pp.495-502.

Loo, L.O. and Rosenberg, R., (1996). Production and energy budget in marine suspension feeding populations: Mytilus edulis, Cerastoderma edule, Mya arenaria and Amphiura filiformis. Journal of Sea Research, 35(1-3), pp.199-207.

Macgregor, C.J. and Warren, C.R., (2006). Adopting sustainable farm management practices within a Nitrate Vulnerable Zone in Scotland: the view from the farm. Agriculture, ecosystems \& environment, 113(1-4), pp.108-119.

Macgregor, C.J. and Warren, C.R., (2016). Evaluating the impacts of Nitrate Vulnerable Zones on the environment and farmers' practices: a Scottish case study. Scottish Geographical Journal, 132(1), pp.1-20.

Margalef, R., (1969). Counting. A manual on methods for measuring primary production in aquatic environments. IBP Handbook, 12, pp.7-14.

McLachlan, A., and Brown, A. C. (2006). The ecology of sandy shores. Second edition. Academic Press, Burlington, MA, USA, pp. 373. 
Neto, J.M., Teixeira, H., Patrício, J., Baeta, A., Veríssimo, H., Pinto, R. and Marques, J.C., (2010). The response of estuarine macrobenthic communities to natural-and human-induced changes: dynamics and ecological quality. Estuaries and Coasts, 33(6), pp.1327-1339.

Noss, R.F., (1990). Indicators for monitoring biodiversity: a hierarchical approach. Conservation biology, 4(4), pp.355-364.

Orive, E., Elliott, M., and De Jonge, V. N. (2013). Nutrients and eutrophication in estuaries and coastal waters (Vol. 164). Developments in Hydrobiology. Kluwer Academic Publishers, Dordrecht, pp. 526594 (Reprinted from Hydrobiologia (475/476))

Paganelli, D., Marchini, A. and Occhipinti-Ambrogi, A., (2012). Functional structure of marine benthic assemblages using Biological Traits Analysis (BTA): a study along the Emilia-Romagna coastline (Italy, North-West Adriatic Sea). Estuarine, Coastal and Shelf Science, 96, pp.245-256.

Patrício, J., Elliott, M., Mazik, K., Papadopoulou, K.N. and Smith, C.J., (2016). DPSIR-two decades of trying to develop a unifying framework for marine environmental management?. Frontiers in Marine Science, 3, p.177.

Pearson, T.H. and Rosenberg, R., (1978). Macrobenthic succession in relation to organic enrichment and pollution of the marine environment. Oceanography and Marine Biology: An Annual Review , 16, pp.229-311.

Petchey, O.L., O'Gorman, E.J. and Flynn, D.F., (2009). A functional guide to functional diversity measures. Biodiversity, Ecosystem Functioning, \& Human Wellbeing Naeem S, Bunker DE, Hector A, Loreau M, Perrings C, eds. Oxford University Press, Oxford, pp.49-59.

Philippart, C.J., (1998). Long-term impact of bottom fisheries on several by-catch species of demersal fish and benthic invertebrates in the south-eastern North Sea. ICES Journal of Marine Science, 55(3), pp.342-352.

Phillips, G.R, Miles, A.C., Prior, A., Martina, L.J., Brooks, L., Anwar, A., (2012). The continued development of a Water Framework Directive classification scheme for the marine benthic invertebrate component: the Infaunal Quality Index. Environment Agency (UK), R\&D Technical Report.

Pielou, E. C. (1969). An introduction to mathematical ecology. An introduction to mathematical ecology. Wiley-Interscience, New York, pp.286.

Pinto, R., de Jonge, V.N., Neto, J.M., Domingos, T., Marques, J.C. and Patrício, J., (2013). Towards a DPSIR driven integration of ecological value, water uses and ecosystem services for estuarine systems. Ocean \& Coastal Management, 72, pp.64-79.

Pinto, R., Patrício, J., Baeta, A., Fath, B.D., Neto, J.M. and Marques, J.C., (2009). Review and evaluation of estuarine biotic indices to assess benthic condition. Ecological indicators, 9(1), pp.1-25.

Piscart, C., Usseglio-Polatera, P., Moreteau, J.C. and Beisel, J.N., (2006). The role of salinity in the selection of biological traits of freshwater invertebrates. Archiv für hydrobiologie, 166(2), pp.185198.

Prophet, R. (2015). An Investigation into the Feasibility of a Micro-hydro Installation for the Guardbridge Energy Centre as Part of a Brownfield Redevelopment. (MSc dissertation, University of University of Strathclyde). 
Queirós, A.M., Birchenough, S.N., Bremner, J., Godbold, J.A., Parker, R.E., Romero-Ramirez, A., Reiss, H., Solan, M., Somerfield, P.J., Colen, C. and Hoey, G., (2013). A bioturbation classification of European marine infaunal invertebrates. Ecology and evolution, 3(11), pp.3958-3985.

Queirós, A.M., Stephens, N., Cook, R., Ravaglioli, C., Nunes, J., Dashfield, S., Harris, C., Tilstone, G.H., Fishwick, J., Braeckman, U. and Somerfield, P.J., (2015). Can benthic community structure be used to predict the process of bioturbation in real ecosystems?. Progress in Oceanography, 137, pp.559-569.

Raffaelli, D.G., (2006). Biodiversity and ecosystem functioning: issues of scale and trophic complexity. Marine Ecology Progress Series, 311, pp.285-294.

Raffaelli, D.G., (2011). Contemporary concepts and models on biodiversity and ecosystem function. Treatise on Estuarine and Coastal Science, 9, pp.5-21.

Riemann, B., Carstensen, J., Dahl, K., Fossing, H., Hansen, J.W., Jakobsen, H.H., Josefson, A.B., Krause-Jensen, D., Markager, S., Stæhr, P.A. and Timmermann, K., (2016). Recovery of Danish coastal ecosystems after reductions in nutrient loading: a holistic ecosystem approach. Estuaries and Coasts, 39(1), pp.82-97.

SEERAD (Scottish Executive Environment Rural Affairs Department), (2003). Maps of Areas Designated as Nitrate Vulnerable Zones in Scotland under the Nitrates Directive (91/676/EC). http://www.scotland.gov.uk/library4/ERADEN/WEU/00016675.aspx [Accessed 18/05/2018]

Shannon, C. E., and Weaver, W. (1963). The measurement theory of communication. University of Illinois Press.

Simpson, E.H., (1949). Measurement of diversity. Nature 163, pp.688.

Solan, M., Cardinale, B.J., Downing, A.L., Engelhardt, K.A., Ruesink, J.L. and Srivastava, D.S., (2004). Extinction and ecosystem function in the marine benthos. Science, 306(5699), pp.1177-1180.

Steckbauer, A., Duarte, C.M., Carstensen, J., Vaquer-Sunyer, R. and Conley, D.J., (2011). Ecosystem impacts of hypoxia: thresholds of hypoxia and pathways to recovery. Environmental Research Letters, 6(2), pp.025003.

Strong, J.A., Andonegi, E., Bizsel, K.C., Danovaro, R., Elliott, M., Franco, A., Garces, E., Little, S., Mazik, K., Moncheva, S. and Papadopoulou, N., (2015). Marine biodiversity and ecosystem function relationships: the potential for practical monitoring applications. Estuarine, Coastal and Shelf Science, 161, pp.46-64.

Teixeira, H., Salas, F., Borja, A., Neto, J.M. and Marques, J.C., (2008). A benthic perspective in assessing the ecological status of estuaries: the case of the Mondego estuary (Portugal). Ecological Indicators, 8(4), pp.404-416.

Thrush, S. F., Halliday, J., Hewitt, J. E., and Lohrer, A. M. (2008). The effects of habitat loss, fragmentation, and community homogenization on resilience in estuaries. Ecological Applications, 18(1), pp.12-21.

Tweedley, J.R., Warwick, R.M. and Potter, I.C., (2015). Can biotic indicators distinguish between natural and anthropogenic environmental stress in estuaries?.Journal of Sea Research, 102, pp.1021. 
van der Linden, P., Patrício, J., Marchini, A., Cid, N., Neto, J.M. and Marques, J.C., (2012). A biological trait approach to assess the functional composition of subtidal benthic communities in an estuarine ecosystem. Ecological Indicators, 20, pp.121-133.

Van Kleef, H.H., Van Duinen, G.A., Verberk, W.C.E.P., Esselink, H., Leuven, R.S.E.W. and van der Velde, G., (2006). Biological traits successfully predict the effects of restoration management on macroinvertebrates in shallow softwater lakes. In Living Rivers: Trends and Challenges in Science and Management, Springer, Dordrecht, pp. 201-216.

Veríssimo, H., Bremner, J., Garcia, C., Patrício, J., van der Linden, P., and Marques, J. C. (2012a). Assessment of the subtidal macrobenthic community functioning of a temperate estuary following environmental restoration. Ecological Indicators, 23, pp.312-322.

Veríssimo, H., Neto, J. M., Teixeira, H., Franco, J. N., Fath, B. D., Marques, J. C., and Patrício, J. (2012b). Ability of benthic indicators to assess ecological quality in estuaries following management. Ecological Indicators, 19, pp.130-143.

Warwick, R.M. and Clarke, K.R., (1995). New 'biodiversity' measures reveal a decrease in taxonomic distinctness with increasing stress. Marine Ecology Progress Series, pp.301-305.

Wu, J. and David, J.L., (2002). A spatially explicit hierarchical approach to modeling complex ecological systems: theory and applications. Ecological modelling, 153(1-2), pp.7-26. 